\title{
Ionised magnesium and calcium in plasma from healthy volunteers and patients undergoing cardiopulmonary bypass
}

\author{
C I O Brookes, C H Fry
}

\begin{abstract}
Objectives-To measure the concentration of ionised magnesium, $\left[\mathrm{Mg}^{2+}\right]$, and ionised calcium $\left[\mathrm{Ca}^{2+}\right]$, in plasma from healthy volunteers and patients undergoing cardiopulmonary bypass (CPB). These measurements were carried out because there have been few reliable measurements of these values in healthy volunteers and no direct measurements in this patient group.

Patients and methods-Dip cast ion selective electrodes were used to measure $\mathrm{Mg}^{2+}, \mathrm{Ca}^{2+}$, and $\mathrm{H}^{+}$in plasma at $37^{\circ} \mathrm{C}$. These values were correlated with total metal concentrations, [Mg] and [Ca], plasma sodium [Na], and albumin concentrations found by standard techniques. Blood samples were taken from the patient group immediately before and after CPB and a further sample 24 hours later.
\end{abstract}

Results-In healthy volunteers the [Mg] was $0.86(0.12) \mathrm{mM}$ and $\left[\mathrm{Mg}^{2+}\right]$, was 0.48 $(0.06) \mathrm{mM}$, and the corresponding value for [Ca] was $2.34(0.06)$ and for $\left[\mathrm{Ca}^{2+}\right]$ $1.01(0.13) \mathrm{mM}$. Values for [Mg], [Ca], and $\left[\mathrm{Ca}^{2+}\right]$ have been reported by others and those quoted here are similar. In the CPB group the preoperative [Mg] was lower than the normal group but did not alter one hour after CPB and was slightly raised after 24 hours. The $\left[\mathrm{Mg}^{2+}\right]$, however, was significantly reduced after 24 hours. Both [Ca] and $\left[\mathrm{Ca}^{2+}\right]$ were slightly reduced after 24 hours but when adjusted for plasma albumin concentrations they were unchanged over this period.

Conclusions-The most important finding is that around 24 hours after CPB the plasma $\left[\mathrm{Mg}^{2+}\right]$ is significantly reduced, with no change to the total [Mg] Corresponding changes to [Ca] and $\left[\mathrm{Ca}^{2+}\right]$ were much smaller. This supposes the presence of an $\mathbf{M g}^{2+}$ binding ligand of unknown origin in the plasma that may contribute to the cardiac arrhythmias that occur in some patients at this time after CPB.

\section{(Br Heart f 1993;69:404-408)}

The importance of plasma magnesium concentrations $[\mathrm{Mg}]$ in determining cardiovascular function is increasingly becoming recognised. ${ }^{1}$ Hypomagnesaemia is associated with myocardial injury, dysrhythmias, hypercoagulability, ${ }^{2}$ arterial hypertension, ${ }^{3}$ and coronary vasospasm. ${ }^{4}$ Patients with acute myocardial infarction or congestive heart failure are more likely to experience ventricular arrhythmias and fibrillation if hypomagnesaemic, ${ }^{5}$ and the deficiency has been implicated in several other arrhythmias, including torsades de pointes, ${ }^{6}$ multifocal atrial tachycardia, ${ }^{7}$ and those induced by digoxin. ${ }^{8}$ Several studies have suggested that $\mathrm{Mg}$ infusion after acute myocardial infarction will reverse many arrhythmias ${ }^{910}$ and limit infarct size and mortality ${ }^{11-13}$; follow up studies showed that $\mathrm{Mg}$ treatment reduced mortality after one year, which was related to the reduction of arrhythmias and infarct size during the first week after infarction. ${ }^{14}$

Plasma $\mathrm{Mg}$ exists in two states: bound to covalent ligands such as plasma proteins, or freely ionised $\left(\mathrm{Mg}^{2+}\right)$. It is only $\mathrm{Mg}^{2+}$ that exerts biological activity so that any alteration to the concentration of $\mathbf{M g}^{2+}$ binding ligands would alter the freely ionised concentration $\left[\mathrm{Mg}^{2+}\right]$ without any change of values of total plasma $\mathrm{Mg}[\mathrm{Mg}]$. The studies listed have all relied on measurement of $[\mathrm{Mg}]$ so that more significant relations between hypomagnesaemia and cardiovascular function may have been obscured. Direct measurement of $\mathbf{M g}^{2+}$ with ion selective electrodes in extracellular fluids has until recently been hampered by the poor selectivity of $\mathbf{M g}^{2+}$ selective ligands over interfering ions such as $\mathrm{Na}^{+}$and $\mathrm{Ca}^{2+}$. Also, negatively charged plasma proteins have caused electrode drift, precluding accurate calibration. These problems have been largely overcome by the development of more selective $\mathrm{Mg}^{2+}$ sensitive neutral ligands ${ }^{15}$ and improvements in the design of the ion selective electrodes. ${ }^{16} \mathrm{~A}$ value of $0.71 \mathrm{mM}$ is quoted for $\left[\mathrm{Mg}^{2+}\right]$ and $0.92 \mathrm{mM}$ is quoted for $[\mathrm{Mg}]$ at room temperature. ${ }^{15}$

We have measured total and freely ionised $\mathrm{Mg}$ and $\mathrm{Ca}$ in plasma samples from healthy volunteers and patients undergoing cardiopulmonary bypass (CPB) surgery. We find that there are no large changes to [Ca] and $[\mathrm{Mg}]$ after such surgery but that $\left[\mathrm{Mg}^{2+}\right]$ falls after several hours. This is not associated with a corresponding reduction in $\left[\mathrm{Ca}^{2+}\right]$.

Patients and methods

ION SELECTIVE ELECTRODE MANUFACTURE AND CALIBRATION

Manufacture

Electrodes were manufactured from PVC tube with a ceramic plug over which was cast a thin layer of ion sensitive material. The ion sensitive materials used were: $\mathbf{M g}^{2+}, \mathrm{ETH}$ 
5282 or ETH $7025\left(3 \cdot 3 \%\right.$ w/w); $\mathrm{Ca}^{2+}, \mathrm{ETH}$ $1001(3.3 \% \mathrm{w} / \mathrm{w})$; and $\mathrm{H}^{+}$, tri $\mathrm{n}$-dodecylamine $(1.0 \% \mathrm{w} / \mathrm{w})$. These materials were incorporated in a PVC matrix $(31.6 \% \mathrm{w} / \mathrm{w}$ $\mathrm{Mg}^{2+}$ and $\mathrm{Ca}^{2+}$, or $32 \cdot 8 \% \mathrm{w} / \mathrm{w} \mathrm{H}^{+}$) containing also bis (2-ethylhexyl) sebacate $(63.0 \% \mathrm{w} / \mathrm{w}$, $\mathrm{Mg}^{2+}$ and $\mathrm{Ca}^{2+}$, or $65.7 \% \mathrm{w} / \mathrm{w}, \mathrm{H}^{+}$) and $\mathrm{K}$ tetrakis-[4-chlorophenyl borate] $(2 \cdot 2 \% \mathrm{w} / \mathrm{w}$, $\mathrm{Mg}^{2+}$ and $\mathrm{Ca}^{2+}$, or $0.5 \% \mathrm{w} / \mathrm{w} \mathrm{H} \mathrm{H}^{+}$). Full details of the manufacturing processes have been described. ${ }^{16}{ }^{17}$ Selective electrodes for $\mathrm{Mg}^{2+}$ were filled with $1 \mathrm{mM} \mathrm{MgCl}$ and $150 \mathrm{mM} \mathrm{NaCl}$, $\mathrm{Ca}^{2+}$ sensitive electrodes with $1 \mathrm{mM} \mathrm{CaCl}{ }_{2}$ and $150 \mathrm{mM} \mathrm{NaCl}, \mathrm{H}^{+}$sensitive electrodes with $58 \mathrm{mM} \mathrm{Na}$ citrate, $29 \mathrm{mM}$ citric acid, and $63 \mathrm{mM} \mathrm{NaCl}$. All filling solutions were saturated with $\mathrm{AgCl}$. All materials were from Fluka Chemicals, Derbyshire, except ETH 5282 and ETH 7025, which were gifts from Professor W Simon, ETH, Zürich. A single streaming $3 \mathrm{M} \mathrm{KCl}$ liquid junction was used as a reference electrode. The potential difference between the reference and each ion selective electrode was measured with a high input impedance operational amplifier $\left(<10^{12} \Omega\right)$ and the values were displayed on a digital read out.

\section{Calibration}

Electrodes semsitive to $\mathbf{M g}^{2+}$ were calibrated in a solution in which the $\left[\mathrm{MgCl}_{2}\right]$ varied between 0.3 and $10 \mathrm{mM}$ and also contained $140 \mathrm{mM} \mathrm{NaCl}, 0-2 \mathrm{mM} \mathrm{CaCl}$ and $10 \mathrm{mM}$ $\mathrm{N}$-[2-hydroxyethyl] piperazine-N'-[2-ethanesulphonic acid] (HEPES), pH 7·4. Electrodes sensitive to $\mathrm{Ca}^{2+}$ were calibrated in a solution in which the $\left[\mathrm{CaCl}_{2}\right]$ varied between 0.5 and $10 \mathrm{mM}$ and also contained $140 \mathrm{mM} \mathrm{NaCl}$, 0-1 $\mathrm{mM} \mathrm{MgCl}_{2}$ and $10 \mathrm{mM}$ HEPES, $\mathrm{pH} \mathrm{7 \cdot 4}$. Electrodes sensitive to $\mathrm{H}^{+}$were calibrated with phosphate buffers made to $\mathrm{pH} 7 \cdot 38$ and $6 \cdot 84$. Figure 1 shows calibration curves for

Figure 1 Calibration curves of $\mathrm{Mg}^{2+}(A)$ and $\mathrm{Ca}^{2+}(B)$ sensitive electrodes. The ordinate in each curve is arbitrarily set at $0 \mathrm{mV}$ in $10 \mathrm{mM}$ of the primary ion, $\mathrm{Mg}^{2+}$ respectively. Values are mean (SD), $n=2-6$ either $\mathrm{Mg}^{2+}(A)$ or $\mathrm{Ca}^{2+}(B)$ selective electrodes. In $(A)$ curves are shown in the absence or presence of $1 \mathrm{mM} \mathrm{CaCl}{ }_{2}$. In $(B)$ the $\mathrm{Ca}^{2+}$ electrode was calibrated in solutions containing zero and $1 \mathrm{mM} \mathrm{MgCl}$. The $\mathrm{Mg}^{2+}$ electrode showed a response to $\mathrm{Ca}^{2+}$. This was evident as a reduced sensitivity at low $\left[\mathrm{Mg}^{2+}\right]$ in the presence of $1 \mathrm{mM} \mathrm{CaCl}{ }_{2}$. In theory an electrode selective only to the primary ion $\left(\mathrm{Mg}^{2+}\right.$ or $\left.\mathrm{Ca}^{2+}\right)$ should exhibit a linear response with the axes of fig 1 . The continued deviation from linearity in zero $\mathrm{Ca}$ $(A)$ and zero $\mathrm{Mg}$ solution $(B)$ reflects interference from $\mathrm{Na}^{+}$. The range of $\left[\mathrm{Na}^{+}\right]$in the plasma samples was between 125 and 145 $\mathrm{mM}$, and in separate experiments variation of the $\left[\mathrm{Na}^{+}\right]$in this range had no effect on the calibration curves of either electrode. Addition of $5 \mathrm{mM} \mathrm{KCl}$ or $20 \mathrm{mg} / \mathrm{ml}$ bovine serum albumin to the calibrating solutions were also without effect on the calibration curves. Thus it may be concluded that variation of plasma $\left[\mathrm{Na}^{+}\right],\left[\mathrm{K}^{+}\right]$or protein concentration would not influence the electrode readings.

\section{CLINICAL AND EXPERIMENTAL METHODS \\ Blood samples and analysis}

Venous blood $(20 \mathrm{ml})$ was drawn through intravenous lines from 12 healthy volunteers and 20 patients undergoing cardiopulmonary bypass (CPB) for either coronary vein grafting or valve replacement. Blood was taken about one hour before CPB, about one hour after CPB, and then 24 hours after CPB. Samples were immediately centrifuged at $1000 \mathrm{~g}$ for 10 minutes and the plasma fraction was divided into two. One was frozen at $-20^{\circ} \mathrm{C}$ for subsequent measurement of $\mathrm{Mg}^{2+}$ and $\mathrm{Ca}^{2+}$, the second was retained for analysis of $\mathrm{Na}^{+}, \mathrm{K}^{+}$, albumin, total protein, [Ca], and $[\mathrm{Mg}]$. From the retained sample $1 \mathrm{ml}$ was used to find the $\left[\mathrm{Na}^{+}\right]$and $\left[\mathrm{K}^{+}\right]$with a Synchron CX analyser, which incorporates a glass $\mathrm{Na}^{+}$sensitive electrode and a valinomycin based $\mathrm{K}^{+}$sensitive electrode. Albumin concentration was measured spectrophotometrically with bromcresol green $\left(A_{\max }=628\right.$ $\mathrm{nm})^{18}$ and the rest of the retained sample was acidified with $\mathrm{HCl}(<\mathrm{pH} 1.5)$ for measurement of $[\mathrm{Mg}]$ and $[\mathrm{Ca}$ by atomic absorption spectrophotometry. Measurement of $[\mathrm{Mg}]$ included a reaction with calmagite (COBOS BioAnalyser, Roche UK). Patients undergoing CPB formed two groups. One group received St. Thomas's cardioplegic solution (containing $16 \mathrm{mmol} \mathrm{MgCl}_{2}$ ) and the other (whose hearts were made to fibrillate) received a single bolus of $16 \mathrm{mmol} \mathrm{MgSO}_{4}$. No differences in the results between these two groups were found. Rhythm disturbances were documented through continuous electrocardiographic monitoring and records were kept of plasma [Na], $\mathrm{K}$ requirements, frusemide supplements, and antiarrhythmic drugs.

Experimental protocol and calculations

Measurements were carried out in a water jacketted chamber at $37^{\circ} \mathrm{C}$ into which protruded a reference, $\mathrm{Mg}^{2+}, \mathrm{Ca}^{2+}$, and $\mathrm{H}^{+}$ 
sensitive electrodes. Electrodes were initially calibrated in the appropriate solutions after which the plasma sample was introduced into the chamber. The $\mathrm{pH}$ of the plasma sample was maintained between 7.37 and 7.45 and readings from the $\mathrm{Ca}^{2+}$ and $\mathrm{Mg}^{2+}$ selective electrodes taken. The influence of $\mathrm{Mg}^{2+}$ on the $\mathrm{Ca}^{2+}$ sensitive electrode is minimal (fig 1B) so that the plasma $\left[\mathrm{Ca}^{2+}\right]$ could be determined directly from the $\mathrm{Ca}^{2+}$ electrode reading and the calibration curve. The effect of $\mathrm{Ca}^{2+}$ on the $\mathrm{Mg}^{2+}$ electrode was significant and it was necessary to calibrate the $\mathbf{M g}^{2+}$ electrode again in a solution in which the $\left[\mathrm{Ca}^{2+}\right]$ was that measured by the $\mathrm{Ca}^{2+}$ electrode. This calibration curve was then used to find the $\left[\mathrm{Mg}^{2+}\right]$ of the plasma sample. To ascertain the accuracy with which the $\mathbf{M g}^{2+}$ selective electrode could measure $\mathrm{Mg}^{2+}$ in the presence of $\mathrm{Ca}^{2+}$, in some experiments $4 \mathrm{mM}$ ethylene glycol tetra-acetic acid was added (at constant $\mathrm{pH}$ ) to different fractions of the plasma sample to chelate $\mathrm{Ca}^{2+}$, and the $\left[\mathrm{Mg}^{2+}\right]$ was again measured. It was judged that $\mathrm{Mg}^{2+}$ ions were not bound by this procedure because of the lack of a $\mathrm{pH}$ change when $\mathrm{MgCl}_{2}$ was added to the sample. In this situation the $\mathrm{Mg}^{2+}$ selective electrode was calibrated in solutions containing no added $\mathrm{Ca}^{2+}$. Similar results were found with both procedures indicating that $\mathrm{Ca}^{2+}$ interference could be accurately estimated.

\section{Results}

VALUES IN PLASMA FROM NORMAI

VOLUNTEERS

The $[\mathrm{Mg}],\left[\mathrm{Mg}^{2+}\right],[\mathrm{Ca}]$, and $\left[\mathrm{Ca}^{2+}\right]$ were measured in the plasma of 12 healthy volunteers (table). The proportion of $\left[\mathrm{Mg}^{2+}\right]$ and $\left[\mathrm{Ca}^{2+}\right]$ compared with $[\mathrm{Mg}]$ and [Ca] was $56 \%$ for $\mathrm{Mg}$ and $43 \%$ for $\mathrm{Ca}$. The variability of these values was investigated by measuring each of them over five successive days. Blood samples were taken from three subjects at mid morning each day and the plasma was separated immediately. There was no significant trend in any of the values over this period. For these three subjects the values obtained on the first day have been included in the table.

Total and freely ionised magnesium and calcium ([Mg], [Ca], $\left[\mathrm{Mg}^{2+}\right]$ and $\left[\mathrm{Ca}^{2+}\right]$ ), $\left[\mathrm{Na}^{+}\right]$, and albumin concentrations in plasma from healthy volunteers and patients undergoing cardiopulmonary bypass

\begin{tabular}{|c|c|c|c|c|}
\hline \multirow[b]{2}{*}{ Variable } & \multirow[b]{2}{*}{ Controls } & \multirow[b]{2}{*}{ Before operation } & \multicolumn{2}{|c|}{ After operation } \\
\hline & & & $1 \mathrm{~h}$ & $24 h$ \\
\hline $\begin{array}{l}{[\mathrm{Mg}](\mathrm{mM})} \\
{\left[\mathrm{Mg}^{2+}\right](\mathrm{mM})} \\
{[\mathrm{Ca}](\mathrm{mM})} \\
{\left[\mathrm{Ca}^{2+}\right](\mathrm{mM})} \\
{[\mathrm{Na}](\mathrm{mM})} \\
\text { Albumin }(\mathrm{mg} / \mathrm{ml}) \\
{\left[\mathrm{Mg}^{2+} / \text { lbumin }\right.} \\
{\left[\mathrm{Mg}^{2+}\right] / \text { albumin }} \\
{\left[\mathrm{Ca}^{2} / \text { albumin }\right.} \\
{\left[\mathrm{Ca}^{2+}\right] / \text { albumin }}\end{array}$ & $\begin{array}{l}0.86(0.12) \\
0.48(0.06) \\
2.34(0.06) \\
1.01(0.13) \\
145(1)\end{array}$ & $\begin{array}{l}0.67(0.07)^{\star} \\
0.53(0.16) \\
2.25(0.15) \\
1.07(0.27) \\
138(5) \\
36.9(5.0) \\
0.018(0.002) \\
0.014(0.004) \\
0.062(0.008) \\
0.029(0.008)\end{array}$ & $\begin{array}{l}0.70(0.09) \\
0.50(0.17)\end{array}$ & $\begin{array}{l}0.73(0.11)^{\star} \\
0.18(0.05)^{\star \star \star} \\
2.06(0.10)^{\star \star \star} \\
0.95(0.27)^{\star \star} \\
139(3) \\
33.6(4.6)^{\star} \\
0.022(0.004)^{\star \star} \\
0.005(0.001)^{\star \star \star} \\
0.062(0.007) \\
0.029(0.008)\end{array}$ \\
\hline
\end{tabular}

VALUES IN PLASMA FROM PATIENTS UNDERGOING CPB

The table shows values from 20 patients who underwent CPB during cardiac surgery. Samples were taken immediately before the operation in the premedication room, one hour after CPB, and a final one 24 hours after bypass. The table also shows values of plasma $\left[\mathrm{Na}^{+}\right]$, and albumin. The albumin values were measured to correct the magnesium and calcium concentrations for any possible net dilution or concentration of the plasma over the period of examination. Figure 2 shows these values of $[\mathrm{Mg}],[\mathrm{Ca}]$, $\left[\mathrm{Mg}^{2+}\right]$, and $\left[\mathrm{Ca}^{2+}\right]$ before and after CPB.

All 20 patients received $\mathrm{K}$ supplements to maintain their serum concentrations at 4-5 $\mathrm{mmol} / \mathrm{l}$. These requirements varied between 20 and $150 \mathrm{mmol}$ in the 24 hours after CPB (mean (SD) 76 (30) mmol). There was, however, no correlation between the $\mathrm{K}$ requirement and $[\mathrm{Mg}],[\mathrm{Ca}],\left[\mathrm{Mg}^{2+}\right]$, or $\left[\mathrm{Ca}^{2+}\right] 24$ hours after CPB. Frusemide supplements were given to improve urine output in 13 patients, varying between 20 and $250 \mathrm{mg}$ over the 24 hour period, and again no correlation was found between $[\mathrm{Mg}],[\mathrm{Ca}]$, $\left[\mathrm{Mg}^{2+}\right]$, or $\left[\mathrm{Ca}^{2+}\right]$ and diuretic quantity given 24 hours after CPB. Antiarrhythmic treatment was necessary for five patients who had rhythm disturbances in this period. Four patients had paroxysmal atrial tachyarrhythmias and received digoxin or amidorone, and one patient had haemodynamically significant ventricular extrasystoles that were suppressed with lignocaine.

Figure 2 shows that one hour after $\mathrm{CPB}$ $[\mathrm{Mg}]$ and $\left[\mathrm{Mg}^{2+}\right]$ were unaltered compared with the preoperative values. After 24 hours, however, $\left[\mathrm{Mg}^{2+}\right]$ was significantly reduced by a mean (SD) of $0.35(0.15) \mathrm{mM}$, despite a small but significant rise in $[\mathrm{Mg}]$. The $\left[\mathrm{Ca}^{2+}\right]$ and $[\mathrm{Ca}]$ both showed small but significant reductions. The plasma $\left[\mathrm{Na}^{+}\right]$was not signifi-

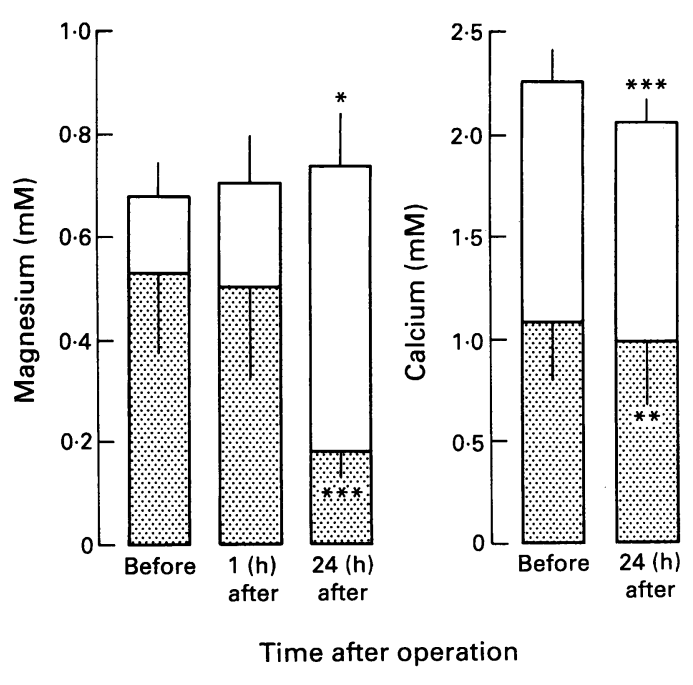

Figure 2 Values of [Mg] and [Ca] (whole box) and $\left[\mathrm{Mg}{ }^{2+}\right]$ and $\left[\mathrm{Ca}^{2+}\right]$ (shaded box) in plasma samples from patients undergoing cardiopulmonary bypass surgery.

pamples were taken before operation and one and 24 hours after surgery. Significance values are compared with the preoperative value, $\star_{p}<0.05 ;{ }^{\star} p<0.01 ;{ }^{\star \star \star} \neq<<0.001$ Values are mean (SD), $n=20$. 
cantly changed throughout the experimental period, but plasma albumin concentrations were reduced 24 hours after CPB. Division of $[\mathrm{Mg}],[\mathrm{Ca}],\left[\mathrm{Mg}^{2+}\right]$ and $\left[\mathrm{Ca}^{2+}\right]$ by the $\left[\mathrm{Na}^{+}\right]$ of each sample gave the same conclusions as those found from comparing the individual concentrations and have not been included in the table. Division by the albumin concentrations of each sample altered some of the conclusions compared with the unaltered values. The $\left[\mathrm{Mg}^{2+}\right]$ remained significantly reduced and was still accompanied by a small rise in $[\mathrm{Mg}]$. The [Ca] and the $\left[\mathrm{Ca}^{2+}\right]$ ratios, however, were now similar both before and 24 hours after CPB.

The $[\mathrm{Mg}]$ and $\left[\mathrm{Mg}^{2+}\right]$ were compared between the small group of patients $(n=5)$ showing dysrhythmias and those who remained in sinus rhythm $(n=15)$. No significant differences were found with either variable $([\mathrm{Mg}] \quad 0.80(0.14)$ v $0.71 \quad(0.09)$ : $\left[\mathrm{Mg}^{2+}\right]$ 0.17 (0.04) v 0.19(0.06)).

\section{Discussion}

The experiments have shown that $\left[\mathrm{Mg}^{2+}\right]$ and $\left[\mathrm{Ca}^{2+}\right]$ in plasma can be measured and changes detected under particular conditions. The $\mathbf{M g}^{2+}$ selective electrodes showed significant and variable $\mathrm{Ca}^{2+}$ sensitivity which needed correction in the samples both to measure $\mathrm{Mg}^{2+}$ and to maintain constant $\mathrm{pH}$. Figure $1(A)$ shows the calibration curves of the three electrodes used in our study, but many other electrodes exhibited a greater $\mathrm{Ca}^{2+}$ interference, which rendered them useless. Further work is required to be able to manufacture consistently usable electrodes.

About $60 \%$ of the total $\mathrm{Mg}$ in plasma from normal volunteers is ionised. This value is similar to that found by others at room temperature. ${ }^{15}$ The concentration and fraction of $\mathrm{Ca}^{2+}$ is also similar to that measured by others. ${ }^{19}$ It is of interest that with the small data sets reported here the preoperative $[\mathrm{Mg}]$ was significantly less in patients about to undergo CPB than that in healthy volunteers (table 1: $0.67(0.07) \quad v \quad 0.86 \quad(0.12) ; \mathrm{p}<0.001$, unpaired $t$ test). The $\left[\mathrm{Mg}^{2+}\right]$ was not dissimilar (table 1: $0.53(0.16)$ v $0.48(0.06) ; \mathrm{p}>$ 0.05 , unpaired $t$ test) and shows that alterations to $[\mathrm{Mg}]$ are not necessarily reflected in the ionised fraction. One possible reason for the low $[\mathrm{Mg}]$ in the patient group is that all but six were taking frusemide as a diuretic, which is known to lead to both $\mathrm{K}^{+}$and $\mathbf{M g}^{2+}$ loss in the urine. ${ }^{20}$ No significant differences were measured in either $[\mathrm{Ca}]$ or $\left[\mathrm{Ca}^{2+}\right]$ in the two groups.

Cardiac standstill in this patient group at St Thomas's Hospital was induced with either hypothermic cardioplegic solution, containing $16 \mathrm{mM} \mathrm{MgCl}{ }_{2}{ }^{21}$ or the patients were made to fibrillate and given a single bolus of $16 \mathrm{mmol} \mathrm{MgCl}_{2}$. It is anaesthetic policy at this hospital to give $\mathrm{Mg}$ before CPB as significant hypomagnesaemia has been shown to follow cardiac surgery without this supplement. ${ }^{22}$ Therefore it was not possible to compare these data with those from patients not receiving $\mathrm{MgCl}_{2}$ during CPB. An original objective was to find whether $[\mathrm{Mg}]$ and $\left[\mathrm{Mg}^{2+}\right]$ were raised in such patients who had undergone CPB. No differences, however, in $[\mathrm{Mg}]$ or $\left[\mathrm{Mg}^{2+}\right]$ were recorded immediately after bypass, but 24 hours later $\left[\mathrm{Mg}^{2+}\right]$ was significantly lowered, despite a small but significant rise in $[\mathrm{Mg}]$. The $[\mathrm{Mg}]$ data should be compared with those of others who also noted a transient hypermagnesaemia. ${ }^{22} 23$ The fact that $\left[\mathrm{Mg}^{2+}\right]$ fell some hours after CPB may be implicated in the high incidence of arrhythmias at about this time ${ }^{24}$ and suggests that such problems may be reversed by $\mathbf{M g}$ infusion. We noted a $25 \%$ incidence of arrhythmias in our small sample but we were unable to correlate $\left[\mathrm{Mg}^{2+}\right]$ with the presence of such disturbances. Such arrhythmias cannot be explained by hypokalaemia as supplementation with $\mathrm{K}$ maintained normal physiological values throughout this period. Clearly a larger sample needs to be studied to clarify the relation between $\left[\mathrm{Mg}^{2+}\right]$ and arrythmogenesis.

Such measurements imply that there is an increase in some $\mathrm{Mg}^{2+}$ binding ligand during the first 24 hours after operation and may be related to the solutions used after $C P B$ or some factor released into the blood stream perioperatively. This ligand would seem to have a preference to bind $\mathrm{Mg}^{2+}$ over $\mathrm{Ca}^{2+}$. Despite the higher initial $\left[\mathrm{Ca}^{2+}\right]$ compared with $\left[\mathrm{Mg}^{2+}\right]$ either preoperatively or immediately after operation, the $\left[\mathrm{Mg}^{2+}\right]$ fell by 0.35 $(0 \cdot 15) \mathrm{mM}$ but the $\left[\mathrm{Ca}^{2+}\right]$ was reduced by only $0.12(0.16) \mathrm{mM}$. The difference between the two reductions is significant $(p<$ $0 \cdot 001)$. The fall of $\left[\mathrm{Mg}^{2+}\right]$ was highly correlated to the preoperative $\left[\mathrm{Mg}^{2+}\right](r=0.96, \mathrm{p}$ $<0.001$ ) so that a constant proportion was removed from the plasma at this time whereas such a correlation was lacking with the $\left[\mathrm{Ca}^{2+}\right]$ data. Moreover the reduction of both $[\mathrm{Ca}]$ and $\left[\mathrm{Ca}^{2+}\right]$ was mirrored by a reduction of the plasma albumin concentration, so that when the $[\mathrm{Ca}]$ and the $\left[\mathrm{Ca}^{2+}\right]$ were corrected for a unit albumin concentration (table) there was no significant fall of either variable. The reduction of ionised $\left[\mathrm{Mg}^{2+}\right]$ and the increase of total $[\mathrm{Mg}]$ were both accentuated when adjusted for the albumin concentration, which suggests that a ligand with a specificity for $\mathbf{M g}^{2+}$ over $\mathrm{Ca}^{2+}$ must be present during this period. One possibility is that components of plasma substitutes used during and after surgery persist for a considerable time. All patients received hetastarch, which may show divalent cation binding ability. In vitro experiments will find if this is a likely possibility. Another possibility is that acute phase proteins released in response to operative stress may show such selective binding. Such a hypothesis may be tested by making measurements on plasma samples taken from patients undergoing laparotomy or those who have had extensive trauma.

In conclusion, these experiments show that measurement of $\left[\mathrm{Mg}^{2+}\right]$ is possible in plasma samples if care is taken to also measure the 
$\left[\mathrm{Ca}^{2+}\right]$ to allow for correction of effects of interferance. Moreover, significant changes to the $\left[\mathrm{Mg}^{2+}\right]$ can take place independently of $[\mathrm{Mg}]$. If the ionised fraction is that which exerts biological actions on cardiac and vascular smooth muscle some caution must be exercised when interpreting data from measurements of total $\mathrm{Mg}$ in plasma.

We are grateful to the research endowments committee of St Thomas's Hospital for financial help, to Professor W Simon for the of for discussion and assistance in obtaining the blood samples.

1 Millane TA, Camm AJ. Magnesium and myocardium. $\mathrm{Br}$ Heart 7 1992;68:441-2.

2 Seelig M. Cardiovascular consequences of magnesium deficiency and loss: pathogenesis, prevalence and manifestations-magnesium and chloride loss in refractory potassium repletion. $A m \mathcal{f}$ Cardiol 1989;63:4-21G

3 Altura BM, Altura BT, Gebrewold A, Ising H, Günther T. Magnesium deficiency and hypertension: corelation between magnesium-deficient diets and microcirculatory changes in situ. Science 1984;223:1315-7.

4 Turlapaty PDMV, Altura BM. Magnesium deficiency produces spasms of coronary arteries: relationship of aetiology of sudden death ischaemic heart disease. Science 1980;208:198-200.

5 Dyckner T. Serum magnesium in acute myocardial infarction. Relation to arrhythmias. Acta Med Scand 1980; 207:59-66.

6 Tzivoni D, Banai S, Schuger C, Benhorin J, Keren AA, Gottlieb S. Treatment of torsades de pointes with magnesium sulphate. Circulation 1988;77:393-7.

7 Iseri LT, Fairshter RD, Hardeman JL, Brodsky MA. Magnesium and potassium therapy in multifocal atrial tachycardia. Am Heart $f$ 1985;110:789-94.

8 Njinimbam CCG, Ryder KW, Glick MR, Glick SJ, Whang $R$. Identification and treatment of hypomagnesaemia and hypokalaemia in patients receiving digoxin. Clin Chem 1990;36:575.

9 Abraham AS, Rosenmann D, Kramer M, Balkin J, Zion MM, Farbstein H, Eylath U. Magnesium in the prevention of lethal arrhythmias in acute myocardial infarction. tion of lethal arrhythmias in acute
10 Smith LF, Heagerty AM, Bing RF, Barnett DB Intravenous infusion of magnesium sulphate after acute
myocardial infarction: effects on arrhythmias and mortality. Int $\mathcal{F}$ Cardiol 1986;12:175-80.

11 Morton BC, Nair RC, Smith FM, McKibbon TG Poznanski WJ. Magnesium therapy in acute myocardial infarction-a double blind study. Magnesium 1984;3 346-52.

12 Rasmussen HS, McNair P, Norregard P, Backer V, Lindeneg $\mathrm{O}$, Balslov $\mathrm{S}$. Intravenous magnesium in acute myocardial infarction. Lancet 1986; i:234-6.

13 Schecter M, Hod H, Marks N, Behar S, Kaplinsky E, Rabinowitz B. Magnesium therapy and mortality in acute myocardial infarction. Am f Cardiol 1990;66: $271-4$.

14 Rasmussen HS, Gronbaek M, Cintin C, Balslov S, Norregard P, McNair P. One-year death rate in 270 जे patients with suspected acute myocardial infarction, initially treated with intravenous magnesium or placebo Clin Cardiol 1988;11:377-81.

15 Rouilly M, Rusterholz B, Spichiger UE, Simon W. Neutral ionophore-based selective electrode for assaying the activity of magnesium in undiluted blood serum. Clin Chem 1990;36:466-9.

16 Fry CH. The manufacture and use of ion-selective electrodes. के Buchenbach, Germany: Biomeßtechnik-Verlag March $\overrightarrow{0}$ GmbH, 1991:1-51.

17 Band DM, Treasure T. Ion selective electrodes in medicine and medical research. In: Covington A, ed. Ion $\omega$ selective electrode methodology. Baton Rouge, Florida: CRC Press, 1979:41-62.

18 Rodkey FL. Direct spectrophotometric determination of albumin in human serum. Clin Chem 1965;1:478-87.

19 Band DM, Heining MPD, Linton RAF. The in vitro tem- of perature coefficient for plasma ionized calcium. $\mathfrak{f}$ Physiol
$1983 ; 339: 31 \mathrm{P}$.

20 Dykner $T_{0}$ Wester PO. Potassium and magnesium depletion in patients with cardiovascular disease. $A m \mathcal{F}$ 윽 Cardiol 1986;82(suppl A): 11-7.

21 Jynge $P$, Hearse DJ, Feuvray D, Mahalu W, Cankovic- Darracott S, O'Brien K, Braimbridge MV. The St Thomas's hospital cardioplegic solution. Scand $\mathcal{F}$ Thorac Cardiovasc Surg 1981;(suppl 30):1-28.

22 Harris MNE, Crowther A, Jupp RA, Aps C. Magnesium and coronary revascularisation. $B r \quad f$ Anaesth 1988;60:779-83.

23 Fanning WJ, Thomas CS, Roach A, Tomichek R, Alford WC, Stoney WS. Prophylaxis of atrial fibrillation with magnesium sulfate after coronary artery bypass grafting. Ann Thorac Surg 1991;52:529-33.

24 Lauer MS, Eagle KA, Buckley MJ, DeSanctis RW. Atria fibrillation following coronary artery bypass surgery. frog Cardiovasc Dis 1989;31:367-78. 